\title{
Ciudades Caídas. Destrucción y MUndo EN RUINAS EN RELACIÓN DE TEXCOCO DE JUAN BAUTISTA POMAR (1582)
}

FALLEN CITIES. DESTRUCTION AND A WORLD IN RUINS IN Relación de TexCoco by Juan Bautista Pomar (1582)

\author{
María Inés Aldao, ${ }^{1,2}$ \\ ORCID 0000-0001-8325-8194 \\ ${ }^{1}$ Universidad Nacional de La Plata \\ La Plata, Argentina \\ ${ }^{2}$ Universidad de Buenos Aires \\ Buenos Aires, Argentina
}

\begin{abstract}
Resumen
Las crónicas mestizas novohispanas se caracterizan por relatar los orígenes, el pasado y las costumbres de los pueblos cabecera, así como instancias relativas a la conquista y evangelización de México. Sin embargo, mediante un discurso atravesado por la retórica cristiana de la caída de Jerusalén, expresan también las ruinas a partir de las cuales se erige ese nuevo orden, en apariencia, armónico. En este artículo me propongo dar cuenta del relato de la destrucción y del mundo en ruinas que subyace en la voz sutilmente crítica y disidente de las crónicas mestizas novohispanas. Para esto, ejemplifico con Relación de Texcoco (1582) de Juan Bautista Pomar, texto especialmente significativo por su complejo y oscilante locus de enunciación, elemento constitutivo de toda crónica mestiza.
\end{abstract}

Palabras clave: Crónica mestiza, ruinas, destrucción, Relación de Texcoco, Juan Bautista Pomar

\section{Resumo}

As crônicas mestiças hispânicas caracterizam-se por recontar as origens, o passado e as costumes dos principais povos astecas, assim como as instâncias relacionadas com a conquista e a evangelização de México. Porém, através de um discurso atravessado pela retórica cristá da queda de Jerusalém, as crônicas mostram também as ruínas a partir das quais foi erigida essa nova ordem aparentemente harmoniosa. Neste artigo pretendo analisar a história da destruição e do mundo em ruínas que

\section{Abstrac}

Novohispanic mestizo chronicles are characterized by their depiction of the origin, the past and the customs of their main towns and of the issues related to the conquest and evangelization of Mexico. Nevertheless, through a discourse tinged by the Christian rhetoric of the fall of Jerusalem, these chronicles also portray the ruins from which that new order emerged in an apparently harmonious way. In this paper I set out to highlight the themes of destruction and the 
subjaz à voz sutilmente crítica e dissidente das crônicas mestiças hispânicas. Para isso, exemplifico com a Relación de Texcoco (1582) de Juan Bautista Pomar, texto especialmente significativo por seu complexo e oscilante locus de enunciação, elemento constitutivo de toda crônica mestiça.

Palavras-chave: crônica mestiça, ruínas, destruição, Relación de Texcoco, Juan Bautista Pomar. world in ruins that underlie the subtle dissident criticism in the NovoHispanic mestizo chronicles. In order to do so, I give examples taken from Relación de Texcoco (1582) by Juan Bautista Pomar, an especially significant text because of its complex and shifting locus of enunciation, an element which is always present in mestizo chronicles.

Keywords: Mestizo chronicles, ruins, destruction, Relación de Texcoco, Juan Bautista Pomar.

\title{
Destrucción y caos
}

\author{
Ayudad a nuestros señores, \\ los que tienen armas de metal, \\ destruyen la ciudad, \\ destruyen la mexicanidad, \\ ea, esforzaos. \\ "A la manera tlaxcalteca"
}

Contrariamente a lo que se suele suponer acerca de la conquista de México y su consecuente evangelización, la conversión de los indígenas no fue un proceso homogéneo ni exento de desorden y caos. Los pipiltin, ${ }^{1}$ convertidos de modo más o menos sincero mediante una compleja práctica de "opresión-asimilación colonial" (LIENHARD, 1990b, p. 11), tuvieron que elegir la adaptación (GRUZINSKI, 2007b, p. 28). Las crónicas mestizas novohispanas ${ }^{2}$ son el mejor ejemplo de que la evangelización, sin ser por completo exitosa, dio sus frutos, pues son estas crónicas las que perpetúan el

1 Pipiltin: Plural de pilli, “Caballero, noble” (Diccionario Nauatl-Español, 2001, p. 81).

2 Las crónicas mestizas son "un grupo de textos que casi independientemente del origen étnico de sus autores, reelaboran materiales discursivos o reales de la historia americana a través de unos procedimientos narrativos (verbales y/o pictográficos) de tradición heterogénea (indígena y europea)" (LIENHARD, 1983, p. 105). Son mestizos, entonces, el tipo de material utilizado para el relato (crónicas de tradición occidental, códices, oralidad, testimonios) y las operaciones (provenientes de y adquiridos por distintas tradiciones) con que esos materiales son incorporados en cada crónica. 
cristianismo ${ }^{3}$ y dan cuenta de la reacomodación por la que debe optar todo sujeto mestizo, inserto en ambas tradiciones. Con esto me refiero a que, a pesar de los intentos de los misioneros, el sincretismo se perpetuó durante años y obligó en cierta forma al mestizo a valorizar su pasado indígena mediante las normas de la tradición impuesta. En ese sentido, son textos que muestran la efectividad de la labor catequística y misionera, a pesar de que no puedan ser considerados textos evangelizadores.

Sin embargo, y a pesar de las similitudes temáticas y estilísticas respecto de las crónicas de tradición occidental, las crónicas mestizas novohispanas gestan un discurso único que se caracteriza por la enunciación ambivalente. En ellas, su enunciador se posiciona desde un lugar que defiende la conquista y evangelización de México mientras realiza, al mismo tiempo, subrepticias críticas a la violencia de dicha gesta y al cambio traumático que la destrucción de fuentes y palacios, entre otros símbolos, gestó en la cultura local.

En esta oportunidad, me centro en una crónica mestiza especialmente significativa por presentar un relato sólido de las costumbres y características de los pueblos prehispánicos, la elisión del relato de conquista y una postura manifiestamente próxima a la evangelización. Me refiero a Relación de Texcoco, texto finalizado hacia 1582 por el cronista texcocano Juan Bautista Pomar. Propongo que, en esta crónica, los tópicos de la destrucción y las ruinas dejan entrever una crítica al nuevo orden colonial y se presentan como despojos culturales que dicho orden impuesto gestó. Esta estrategia no es un gesto meramente descriptivo de la ciudad arrasada, sino muestra clara de la voz disidente de las crónicas mestizas novohispanas.

\section{Sobre Relación de Texcoco}

Relación de Texcoco de Juan Bautista Pomar ${ }^{4}$ es una de las crónicas que menos atención ha recibido de la crítica y una de las más amputadas del archivo colonial latinoamericano. Forma parte de las Relaciones geográficas,

3 El enunciador de la crónica mestiza se posiciona como sujeto evangelizado, esto es, un sujeto que adhiere a la religión impuesta y reconviene a aquellos que persisten en las prácticas paganas.

4 Juan Bautista Pomar, texcocano, hijo del espańol Antonio de Pomar, colono sin indígenas que no participó en la conquista de México, y de una indígena, hija natural de Nezahualpilli con una de sus siervas, murió en 1590. Era bisnieto del tlatoani texcocano Nezahualcoyotl. Pomar pretendió obtener un lugar relevante dentro de la nobleza indígena texcocana (INOUE OKUBO, 2003, p. 4) y su Relación forma parte de ese intento. Criado como cristiano, aprehendió las costumbres y tradiciones de su madre. Hablaba con igual fluidez español y náhuatl. Fue escribano de su ciudad natal. Redactó una información de servicios por medio de la cual pretendía el trono de su abuelo, petición que fue tomada en cuenta recién hacia 1602 (INOUE OKUBO, 2000, p. 219). En vida, solo obtuvo una parte menor de la herencia, una gran mansión en la que residió hasta su muerte (VÁZQUEZ CHAMORRO, 1991, p. 19). Compuso tres textos: Relación de Texcoco, finalizado en 1582, un conjunto de poemas en náhuatl, Romances de los señores de Nueva España, que algunos historiadores fechan hacia 1585 y, por último, fuera del ámbito literario, una relación con el fin de conseguir el legado de su abuelo. 
"descripciones regionales de América que la Corona había concebido entonces como una necesidad imperiosa para conocer bien sus territorios de ultramar" (BAUDOT y TODOROV, 1990, p. 45), surgidas a raíz de la Instrucción y Memoria de 1577. Consta de una introducción firmada por Pomar y treinta y un capítulos de variada extensión, aunque las copias que se conservan comienzan por el capítulo XI y carecen de los XXVIII y XXIX. El texto culmina de manera abrupta, lo cual sugiere que la crónica terminaba con una conclusión o cierre que, al igual que las pinturas y los apartados iniciales, se ha perdido. La crónica contiene numerosas ilustraciones, hoy extraviadas (a las que el narrador se refiere en diversas oportunidades) y dedicadas a los dioses Tezcatlipoca, Huitzilopochtli y Tlaloc, la ceremonia de jura del tlatoani $i^{5}$ o el peinado de las mujeres, entre otras cuestiones relativas a personajes y costumbres del pasado indígena. Varias páginas han sido rotas y las copias que se conservan no han podido reproducir algunas frases.

Citada casi únicamente como fuente de información historiográfica, resta aún analizar en profundidad este texto, expresivo de la ambigüedad enunciativa del mestizo y que transmite una interesante documentación de las historias antiguas, severos juicios hacia indígenas y españoles, y una lectura singular acerca de los procesos de colonización y transculturación. Por ejemplo, el enunciador de la Relación realiza una crítica bien característica de las crónicas mestizas, aunque más acentuada en ésta: los conquistadores, al entrar en México, mandaron quemar las pinturas de los indígenas (POMAR, 1891, p. 1-2). Esto produjo que los descendientes quedaran "con mucho sentimiento, por haber quedado como a escuras sin noticia ni memoria de los hechos de sus pasados" (POMAR, 1891, p. 2). Por otra parte, afirma el enunciador: varios indígenas, por temor al arzobispo Zumárraga, han quemado pinturas con el fin de evitar la acusación de idolatría (POMAR, 1891, p. 2). De esta manera, la crónica se inicia con una fuerte acusación: la misma cultura que exige redacción precisa y consistente del pasado indígena es responsable del extravío de este. Aquí se presenta el primero de los distanciamientos de quien enuncia desde el discurso del conquistador pero a la vez reprocha a dicha conquista la destrucción que produjo.

\section{Ciudades caídas}

Señala Guy Rozat Dupeyron que las fuentes de tradición indígena buscan introducir la historia americana dentro de la tradición cristiana, de

5 Tlatoani: señor, gobernante, orador (Diccionario Nauatl-Español, 2001, p. 105). El término proviene del verbo tlatoa, que significa "dice, contesta, argumenta, responde" (Diccionario Nauatl-Español, 2001, p. 104). Prefiero esta forma en náhuatl y su plural, tlatoque, ya que para los pueblos amerindios el tlatoani era aquel capacitado no solo para el ejercicio del gobierno sino, también, para la persuasión a través de la palabra. Por eso, no sería correcto considerarlo sinónimo de la forma occidental "rey". 
allí que estén inscriptas en el mundo del mito occidental (2002, p. 136). El enunciador mestizo, cristianizado y defensor de dicha evangelización, aúna la caída de su pueblo con la escritura bíblica, llena de alusiones a la caída de Jerusalén.

Las crónicas mestizas novohispanas están repletas de términos referidos a la destrucción, que toman, sin dudas, de la Biblia: escombros, piedras, ruinas, caída, entre tantos otros. Por ejemplo, en la cita bíblica "Jesús predice la destrucción de Jerusalén", leemos: "Como algunos estaban hablando del Templo, con sus hermosas piedras y los adornos que le habían sido regalados, Jesús les dijo: 'Mírenlo bien, porque llegarán días en que todo eso será arrasado y no quedará piedra sobre piedra'” (LUCAS 21, 5-6). Las alusiones bíblicas sobre la ciudad en ruinas son permanentes: "En ruinas, ruinas y más ruinas lo convertiré todo hasta que venga aquel a quien le pertenece el derecho, a ése lo restableceré" (EZEQUIEL 21, 32); "Oh Dios, los paganos han entrado en tu heredad, han profanado tu santuario, y a Jerusalén la han dejado en ruinas" (SALMO 79, 1); "Esta ciudad quedará convertida en un montón de ruinas para siempre, y jamás volverá a ser edificada" (DEUTERONOMIO 13, 17); "Jerusalén está en ruinas y sus puertas quemadas" (NEHEMÍAS 2, 17). La caída de Jerusalén es, entonces, modelo histórico y simbólico para narrar la otra destrucción, la de Tenochtitlan (ROZAT DUPEYRON, 2002, p. 142). Dicha "caída", según la Biblia, se inscribe en el castigo divino por el pecado de los hombres: "estallará sobre este pueblo la cólera de Dios" (LUCAS 21, 23), mientras que en las crónicas mestizas la responsabilidad de la "ciudad caída" es de la ambición del conquistador.

Sin embargo, también otras "caídas" bíblicas, como la de Babilonia, pueden pensarse como modelos textuales:

Palabra de Yavé, que dijo contra Babilonia: "Díganlo entre las naciones para que lo sepan todos; no lo callen, digan: Babilonia ha caído. Babilonia ha sido tomada. Su dios Bel ha sido humillado, Marduk ha sido derribado, avergonzadas están sus imágenes, espantados sus ídolos.” (JEREMÍAS 50, 1-4)

Esta destrucción recorre por completo el Antiguo Testamento hasta el anuncio de la llegada de Cristo que viene, según las Escrituras, a restaurar lo perdido, simbólica y ediliciamente. Los conventos franciscanos erigidos por sobre (y haciendo uso de) las ruinas de los palacios indígenas son en las crónicas anuncio de una (otra) buena nueva, la llegada de la fe; no obstante, no logran suplir el efecto traumático de la destrucción. ${ }^{6}$

6 Respecto de este mundo en ruinas, Chesterton recoge una anécdota sobre San Francisco. Cuenta que mientras estaba éste orando en la iglesia de San Damián, antiguo y abandonado templo de Asís, escuchó una voz que le decía: "Francisco: ¿̨no ves que mi casa está en ruinas? Anda y restáurala por mi amor" (1974, p. 67-68). 
En este punto, me interesa recordar la postura de Walter Benjamin en la Tesis IX de Tesis sobre la historia:

Hay un cuadro de Klee que se titula Angelus Novus. Se ve en él un ángel, al parecer en el momento de alejarse de algo sobre lo cual clava la mirada. Tiene los ojos desorbitados, la boca abierta y las alas tendidas. El ángel de la historia debe tener ese aspecto. Su rostro está vuelto hacia el pasado. En lo que para nosotros aparece como una cadena de acontecimientos, él ve una catástrofe única, que arroja a sus pies ruina sobre ruina, amontonándolas sin cesar. El ángel quisiera detenerse, despertar a los muertos y recomponer lo destruido. Pero un huracán sopla desde el paraíso y se arremolina en sus alas, y es tan fuerte que el ángel ya no puede plegarlas. Este huracán lo arrastra irresistiblemente hacia el futuro, al cual vuelve las espaldas, mientras el cúmulo de ruinas crece ante él hasta el cielo. Este huracán es lo que nosotros llamamos progreso. (BENJAMIN, 2008, p. 44-45)

Construir a partir de las ruinas algo que no necesariamente va a ser mejor es la postura del enunciador mestizo. Y esa mezcla de resignación, indignación y obligada adecuación al presente que subyace en su relato de la historia es el tono característico de su retórica.

\section{Ruinas}

En las crónicas mestizas novohispanas, el posicionamiento del yo frente a las ruinas difiere si son éstas causadas por la acción del tiempo o gestadas por la mano del hombre. De aquí que la ruina recuerde la magnificencia de lo que hubo y, a la vez, la inexorabilidad de la pérdida.

Respecto de este tema, Aníbal Biglieri detalla la etimología del término: "proviene del latín ruina, derivado a su vez del verbo ruo, entre cuyas varias acepciones figuran las de 'caerse', 'hundirse', 'desplomarse', 'derrumbarse', 'derribar' y 'arrasar', lexemas todos pertenecientes a un mismo (sub)campo léxico, cuyo valor común sería el de 'destrucción'” (2002, p. 85-86).

En El tiempo en ruinas, Marc Augé señala que las ruinas permiten observar la existencia de un tiempo que no es el de los libros de historia ni el de las restauraciones, sino un tiempo "puro", sin fecha, "un tiempo perdido cuya recuperación compete al arte” (2003, p. 7). Las ruinas, afirma Augé, no constituyen el recuerdo de nadie a pesar de tener la forma de un recuerdo, pero se ofrecen a quien las transita como un pasado que hubiera quedado olvidado y que, al mismo tiempo, es capaz de decir algo. Las ruinas son un pasado que sobrevive al observador (2003, p. 88).

Por su parte, en su estudio sobre la poesía de Hölderlin, Carlos Disandro asocia la presencia de las ruinas con un "vestigio rememorante de las deidades" y, por ende, como posibilidad de revelación de lo divino en medio de la 
destrucción (1971, p. 168). Georg Simmel en "The Ruin" estudia la implicancia de la ruina como producto de una fuerza cósmica descendente. En ella, afirma Simmel, se quiebra el equilibrio entre espíritu y naturaleza a favor de esta última. La ruina simboliza cómo la naturaleza re-ocupa el lugar que le corresponde y que la creación del hombre le había arrebatado. Para Simmel, esto se tematiza en un motivo típicamente renacentista: las imágenes de flora y fauna devorando lo que queda de distintos edificios en derrumbe (1965, p. 262-263). Jean Starobinski señala que las ruinas se vuelven, también, parte de esa condición natural: "Un equilibrio se establece, donde los poderes antagonistas de la naturaleza y la cultura se reconcilian luego de nuestro paso, en el momento donde se deshacen las huellas del esfuerzo humano, y donde el salvajismo recupera el terreno perdido" (1964, p. 180). Para Starobinski, la mirada sobre las ruinas produce una intensa melancolía que repercute en la estetización de lo observado al punto de olvidar el porqué de dicha catástrofe (1964, p. 180).

Georg Hegel, por su parte, asocia la ruina con la manifestación de la muerte, y a ésta, con la destrucción de un pueblo. Y ejemplifica: la llegada de los europeos a América significó la devastación de la cultura, de aquí que la ruina sea una condición constitutiva de la historia de la humanidad (2005, p. 266).

La ruina significa, en especial, desde sus despojos: "La ruina de un edificio, sin embargo, significa que donde la obra de arte está muriendo, otras fuerzas y formas, las de la naturaleza, han crecido; y que como el arte vive todavía en la ruina y la naturaleza ya lo habita, ha emergido un nuevo todo, una nueva unidad característica" (SIMMEL, 1965, p. 260). Y, a su vez, enseña: "las ruinas hablan, antes que nada, de destrucción: lo indica su etimología y así lo demuestran por doquier las señales que emiten un mismo mensaje de corruptio y de vanitas. Fugit irreparabile tempus, memento mori son la constante advertencia y admonición de las ruinas" (BIGLIERI, 2002, p. 98).

Destrucción, melancolía y nueva significación caracterizan a las ruinas. No obstante, son fragmentos diseminados y/o re-unidos (que, a su vez, pueden estar intercalados, encimados, convertidos en piezas menores) de las grandes construcciones de antańo. Ese lamento por los fragmentos del pasado que aparece en las crónicas mestizas es, también, manifestación de los pedazos de historia que se van con aquéllos y representación implícita de la diseminación y amputación del archivo colonial americano. 
En los caminos yacen dardos rotos, los cabellos están esparcidos. Destechadas están las casas, enrojecidos tienen sus muros. Anales históricos de la nación mexicana

En Relación de Texcoco el movimiento de acercamiento a la cultura originaria se realiza a través de diversos ejes. En primer lugar, las permanentes referencias a las fuentes indígenas que permitieron al enunciador recopilar la información necesaria para la relación. Según él, su investigación fue realizada "habiendo primero hecho muchas diligencias para ella, buscando indios viejos y antiguos inteligentes [...] y cantares antiquísimos" (POMAR, 1891, p. 1). En segundo lugar, un intento de objetividad como cronista capaz de diferenciar lo bueno y lo malo de sus antepasados. Este enunciador se esfuerza por distinguir "sus costumbres" (POMAR, 1891, p. 25) y releva el papel del arte entre los indígenas, que se encuentra estrechamente relacionado con la transmisión de su memoria. Sin embargo, este enunciador incurre, a su vez, en momentos idílicos e hiperbólicos al narrar las formas de justicia en Texcoco: "Vivían tan justos y tan recatados en hacer justicia", "El rey tenía gran cuidado de en todo se hiciera justicia" (POMAR, 1891, p. 31). Además, toma partido por el pueblo indígena en general: "los indios son muy domésticos y pacíficos unos con otros" (POMAR, 1891, p. 44), "eran fidelísimos y constantes en toda adversidad" (POMAR, 1891, p. 52) y expresiones similares que podemos encontrar en otros cronistas, como Bartolomé de las Casas, Toribio de Benavente Motolinía, Gerónimo de Mendieta o Diego Durán. Así, presenta ese virtuosismo que caracterizaba a Texcoco dejando entrever que la causa de su actual inexistencia es el proceso de colonización que arrasó con la cultura indígena.

Dentro de esta reapropiación de la tradición indígena, el enunciador recupera el pasado de Texcoco desde una visión panegírica. Sin embargo, no lo hace solamente con el fin de revalorizar el prestigio de su pueblo y, así, obtener las mercedes que reclama, sino que, a la vez, se esfuerza por contrarrestar las típicas acusaciones de los españoles a los indígenas en cuanto a la ebriedad, la lujuria, el despotismo de sus monarcas, la crueldad de las guerras, el desaseo, la vagancia, entre otras. Entre los casi dos tercios del texto dedicados al tiempo anterior a la conquista, el enunciador de la Relación pretende demostrar la supremacía religiosa de Texcoco por sobre, por ejemplo, los mexicas (introductores, según él, del sacrificio), pero también la superioridad política de su ciudad. De esta manera, origen, gobierno y religión 
de su pueblo se relevan satisfaciendo la demanda informativa proveniente de la misma sociedad colonial y gestando, a la vez, una cronología crítica de la destrucción impuesta por dicho nuevo orden.

El enunciador realiza un panegírico de la ciudad de Texcoco en tanto señorío extinto, gesto de recuperación del pasado típico de la crónica mestiza novohispana. La antigua Texcoco es una ciudad en la que se castigan los pecados y se juzga al que delinque, las guerras se producen solo si son concertadas con México y Tacuba y hay, también, espacio para el arte. ${ }^{7}$ Según el enunciador, los tlatoque Nezahualpiltzintli y Nezahualcoyotzin fueron rectos e injustamente olvidados (POMAR, 1891, p. 6), a pesar de que tenían pueblos sometidos, lo que puede leerse como justificación para la imposición de poderes $y$, consecuentemente, de religión. El tlatoani cesaba las guerras en caso de hambrunas, brindaba renta para ayudar al pueblo, no cometía excesos y lo castigaba en lo demás. Era amado y respetado. Se rodeaba de un tribunal de justicia compuesto por seis miembros de la nobleza y otros seis alumnos destacados de las casas de educación para macehuales. ${ }^{8}$ Los tlatoque tenían vasallos a su servicio, pero éstos "habían de ser de sus amos humanamente tratados" (POMAR, 1891, p. 42), mención repetida en varias ocasiones que contrasta con la reducción a la servidumbre del indígena por parte del español que el narrador repudia.

Resulta notable el esfuerzo por homologar el antiguo señorío texcocano con el cristianismo. El enunciador asevera que los tlatoque "dudaban de que unos bultos de palo y piedra fueran dioses" y afirma que Nezahualcoyotzin fue quien más buscó al "verdadero dios" (POMAR, 1891, p. 24). Según la Relación, los texcocanos eran monoteístas en forma incipiente y, por esto, propicios para recibir la buena nueva. En la Relación, la estrategia consiste en panegirizar la antigua Texcoco (pujante, justa, armoniosa y en vías de conversión) y destacar su presente: ruinas de los palacios de los tlatoque diseminadas en la ciudad contrastan con ese pasado áureo.

Como plantea Martin Lienhard acerca de las crónicas mestizas,

Independientemente de los móviles invocados para justificar el trabajo de rescatar el discurso indígena, todos estos textos tienden a expresar, entre líneas o más directamente, un "malestar en la Colonia", una disidencia, una crítica del presente colonial. La simple transcripción del discurso indígena hace aparecer un abismo entre la sociedad evocada, la de "antes", y el reino

\footnotetext{
7 "Tenía tiempo para oír cantos, de que eran muy amigos, porque en ellos, como se ha dicho, se contenían muchas cosas de virtud, hechos y hazañas de personas ilustres y de sus pasados, con lo cual levantaba el ánimo a cosas grandes" (POMAR, 1891, p. 35). El arte tenía un estatuto casi idéntico al de la guerra. Es esta una táctica del enunciador para aludir a la importancia de la historia como transmisora de cultura, con lo que pretende incidir en la obtención de aquello que reclama.
}

8 Maseualli: plebeyo o vasallo (Diccionario Nauatl-Español, 2001, p. 64). Su plural es macehualtin. 
de la arbitrariedad que es la Colonia. El carácter en fin de cuentas "explosivo" de las crónicas contaminadas por el discurso indígena explica, sin duda, la censura que se abatió sobre ellas. (1990a, p. 70)

Si el enunciador de otras crónicas, como las misioneras, edifica a partir de las ruinas descritas, basándose en ellas, las crónicas mestizas lamentan dicha pérdida utilizando como basamento la formación religiosa de los mismos frailes para realizar una crítica textual. ${ }^{9}$ En Relación de Texcoco la crítica subrepticia al accionar de los espańoles alcanza al presente colonial. El enunciador, mestizo evangelizado y defensor de esa evangelización, esgrime una crítica a causa de la pérdida de fuentes escritas que la conquista se llevó. Pero, en un movimiento característico de la crónica mestiza, dedica una parte de su texto a la observación de la ciudad, ${ }^{10}$ de la que describe la "buena hechura" para afirmar de inmediato la presencia de sus ruinas:

La forma y edificios de sus casas son bajas, sin sobrado ninguno, unas de piedra y cal, y otras de piedra y barro simple; las más de adobe, de que más usan en esta ciudad, por ser muy buenos, porque los hallamos hoy día a edificios viejos, hechos de más de doscientos años a esta parte, tan enteros y sanos, que largamente pueden servir en edificios nuevos. Tienen las cubiertas con vigas, y en lugar de tablas con muchas astillas muy menudas, tan bien puesta, que no cuela por entre ella ninguna tierra de la que ponen encima para terrado. La mayor parte de ellas tiene su patio, y a la redonda de él los aposentos que han menester, en que tienen sus dormitorios y recibimientos, para hombres en un cabo y en otro para mujeres; y despensas y cocinas y corrales de las casas de los principales y señores, especialmente las de los reyes son muy grandes y de tan poderosas maderas, que casi parece imposible que industria ni fuerzas humanas las pudieran poner en sus lugares, como por las ruinas de ellas hoy se ven en esta ciudad, especialmente en las casas de Nezahualcoyotzin que están en la plaza, que según su grandeza y el sitio y término de ellas, pudieran aposentarse en ellas más de mil hombres. (POMAR, 1891, p. 68)

Observo varias cuestiones importantes en esta cita. Por un lado, la incorporación del tópico de lo inefable, presente también en las crónicas de tradición occidental. Además, el uso de la iteración con preponderancia del

9 Respecto de esta formación recibida en los colegios creados por los misioneros, algunos críticos señalan la importancia de la temática del "mundo en ruinas" en los poemarios del Siglo de oro español (LARA GARRIDO, 1983; LÓPEZ BUENO, 1986; BIGLIERI, 2002), tema que se profundizará durante el Barroco.

10 Utilizo el término "ciudad" consciente de su inadecuación, pues los pueblos mesoamericanos estaban organizados en altépetl y no según la usanza occidental. El altépetl es un tipo de conformación especial en la cual cada territorio conserva su dominio. Es una entidad soberana no equivalente a los términos "pueblo" ni "ciudad" (LOCKHART, 2013, Capítulo II) y designa una realidad doble, compuesta por un territorio y un núcleo urbanizado (GRUZINSKI, 2014, p. 264). 
nexo conector "y" que produce el efecto de inmensidad, pero también de un mundo inacabado o perpetuado, bajo sus restos, en el presente. Por otro lado, una fastuosidad brindada por la sencillez, cualidad especialmente cara al fraile franciscano y, por extensión, al enunciador mestizo. Asimismo, la sinécdoque por la cual el enunciador equipara al tlatoani con su pueblo, gesto típico de la cronística mestiza. En este caso, los aposentos del gobernante solo diferían en tamaño y proporción respecto de las otras casas, lo que indicaría que los tlatoque eran cercanos a su gente y no ídolos inalcanzables, ante los cuales los indígenas bajaban su mirada, tal como se desprende de las crónicas de soldados como Bernal Díaz y Hernán Cortés en referencia al encuentro con Motecuhzoma. Por último, el enunciador señala que, incluso en lo edilicio, Texcoco es un ejemplo para seguir. Mientras todo se derrumba en el presente colonial, la Texcoco antigua se asoma por entre los restos del adobe. Sin embargo y a pesar de esto, también se observan ruinas. Es una ciudad en la que convive el pasado relevado con el presente que se esfuerza por esconder y emerger de esos escombros.

En esta cita se puede apreciar la inadecuación de la enunciación mestiza, en la que confluyen la preponderancia del verbo en presente y el locativo temporal "hoy" con el anuncio de la inexistencia de los palacios del tlatoani. Los conceptos occidentales "reyes" y "ciudad" contrastan con la ańoranza de (parte de) un pasado indígena que se sabe irrecuperable. Si "hoy se ven" ruinas y no aquellas casas de los tlatoque texcocanos, es porque el enunciador oscila entre la jactancia del antiguo poder y la incomodidad, dado que la ruina muestra dicho poderío extinto. Las ruinas del palacio de Nezahualcoyotl enuncian una grandeza pasada y visibilizan la pérdida. La ambivalencia ante esta pérdida es, precisamente, una de las características enunciativas de la crónica mestiza novohispana. Nada más simbólico en la enunciación mestiza que la afirmación de la persistencia de escombros de viejos edificios mientras las casas del tlatoani están en ruinas, es decir, a-rruinadas.

Como plantea Gruzinski, la ciudad que se gesta a partir de la conquista se caracteriza por la superposición, la confusión, el "revoltijo irregular de restos abandonados, edificios indios rehabilitados o destruidos, y casas fortificadas dotadas de torres y de murallas almenadas a la castellana”, compuesta por una población igualmente heterogénea: pipiltin, macehualtin, conquistadores, negros africanos (2007a, p. 82-83). Las ruinas, entonces, son parte de y simbolizan el estado caótico que el mestizo observa en su "ciudad" y que, pese a la evangelización, no puede sino criticar. De un mundo en ruinas, confeccionado con fragmentos de ambas tradiciones, la crónica mestiza tematiza la irrupción de la cultura nueva brindando lugar textual a lo que esta inclusión violenta se lleva consigo. 
En su análisis de la Historia de la nación chichimeca de Fernando de Alva Ixtlilxóchitl, Beatriz Pastor señala la importancia de estas referencias a las ruinas del palacio antiguo en tanto "ausencia que el texto va a intentar llenar" (1999, p. 394). Dicha realidad, hecha de huecos, es un mundo en ruinas que representa el borramiento de la cultura prehispánica mediante un proceso de conquista que redujo el arte a la materia: "destrucción y ruinas enmarcan aquí un texto que se articula como voluntad de llenar el vacío que han dejado la pérdida de las pinturas y la destrucción de los palacios, indicando su función paradigmática" (PASTOR, 1999, p. 395). El relato de la ruina, para Pastor, revela el inicio de lo que llama "el grado cero de la subjetividad del colonizado", esto es,

la fisura simbólica que separa y enlaza el sujeto precortesiano, dueño de su mundo y de su historia, con ese otro sujeto que se define y reencuentra en la experiencia de la desposesión y de la pérdida. Un grado cero que indica simbólicamente el momento de la pérdida misma, el origen de la melancolía y el punto de partida de un discurso posible para los vencidos. (1999, p. 396-397)

Fisura, pérdida, desposesión en el discurso de "los vencidos". La ruina, entonces, se presenta como doblemente traumática: es el palacio que no está, pero a la vez es presencia que recuerda de manera constante la conquista misma.

\section{Consideraciones finales}

Me he servido del ejemplo de Relación de Texcoco entre tantos otros posibles para analizar la presencia de la destrucción y las ruinas en las crónicas mestizas novohispanas. Si a una mirada lábil este tipo de textos puede parecer de posicionamiento enunciativo idéntico al de la crónica de conquistadores (las Cartas de Relación de Hernán Cortés, por ejemplo), una mirada atenta debe detenerse en la alusión a la destrucción posconquista, crítica que, si bien reconoce la importancia del advenimiento de la evangelización, también releva el extravío de parte fundamental de la cultura autóctona. Es esto precisamente lo que señalan estas crónicas que, al no poder manifestar explícitamente simpatía alguna por el pasado pagano, deben hacer uso de la sutileza para erigir una voz no del todo disidente, pero sí detractora del nuevo orden impuesto.

En las crónicas mestizas novohispanas el lamento por lo que ya no está inicia el relato del pasado. A la vez, aquello que describen con mayor sentimiento es lo inexorablemente irrecuperable. De aquí que el enunciador de la Relación dedique la mayor parte de su texto al relato del pasado indígena. En esta crónica resulta fundamental la recopilación de información autóctona de la ciudad, cuyo acceso no habría sido posible para los españoles. Sin embargo, 
a pesar de que incluye pasajes en los que se erige como portavoz de los pipiltin texcocanos, su visión sobre el pasado indígena oscila entre el repudio a sus prácticas paganas y el panegírico, que incluye mucho de la nostalgia por la desaparición. Este hecho de fundar su saber en fuentes orales indígenas aleja al mestizo del discurso occidental y lo inserta en una compleja dialéctica: los cronistas mestizos recurren a la cultura originaria mediante tácticas occidentales para que el saber redunde en un discurso occidentalizado que, en forma y contenido, avale el caótico presente.

La descripción del "presente colonial” en las crónicas mestizas está signada por una presencia incómoda: el caos, la ruina, la destrucción del mundo antiguo, que el enunciador justifica a partir de la inserción de la fe pero que, a la vez y de manera ambivalente, no puede sino signar una crítica a la manera en que se gestó la evangelización. La postura del enunciador de Relación de Texcoco no es de negación del cambio, pero sí de queja explícita por la violencia del mismo. Su mirada, entre nostálgica y resignada, puede resumirse en una de las frases más interesantes del texto: al referirse al antiguo señorío texcocano y a su "mucha variación y mudanza", el enunciador asegura que eso sucedió "como hay en todas las cosas de esta vida" (POMAR, 1891, p. 5), postura que se continúa al manifestar con seguridad que algo del pasado indígena se podría (y debería) haber conservado.

Esta observación sobre el presente colonial, si no extensa, resulta elocuente para atender a la especial situación del mestizo, quien se regodea en su presente evangelizado y, a la vez, muestra una importante predilección por el recuerdo de ese pasado sumergido irremediable e inmutablemente entre los escombros.

\section{Referencias}

AUGÉ, Marc. El tiempo en ruinas. Barcelona: Gedisa, 2003.

BAUDOT, G. \& Todorov, T. Relatos aztecas de la conquista. México: Grijalbo, 1990.

BENJAMIN, Walter. Tesis sobre la Historia y otros fragmentos. México: Editorial Ítaca, 2008.

BIGLIERI, Aníbal. Ruinas romanas y poesía española. Auster, La Plata, n. 6/7, 2002, p. 85-111.

CHESTERTON, Gilbert Keith. San Francisco de Asis. Barcelona: Editorial Juventud, 1974.

Diccionario Nauatl-Español / Español-Nauatl. México: Biblioteca de los Pueblos Indígenas - Instituto Mexiquense de Cultura, 2001. 
DISANDRO, Carlos. "Hölderlin y el sentimiento de las ruinas". In. Modern, R. (ed.). Friedrich Hölderlin 1770-1970: Homenaje en su centenario. La Plata: Universidad Nacional de La Plata - Facultad de Humanidades y Ciencias de la Educación, 1971, p. 163-183.

GRUZINSKI, Serge. El pensamiento mestizo. Cultura amerindia y civilización del Renacimiento. Barcelona: Paidós, 2007.

GRUZINSKI, Serge. La ciudad de México. Una historia. México: Fondo de Cultura Económica, 2014.

GRUZINSKI, Serge. La colonización de lo imaginario. Sociedades indigenas y occidentalización en el México español. Siglos XVI-XVIII. México: Fondo de Cultura Económica, 2007.

HEGEL, Georg Wilhelm Friedrich. Lecciones sobre la Filosofía de la Historia Universal. Madrid: Tecnos, 2005.

INOUE OKUBO, Yukitaka. Pomar y Muñoz Camargo en el contexto históricohistoriográfico de la Nueva España. Históricas. Boletín del Instituto de Investigaciones Históricas de la Universidad Nacional Autónoma de México. n 66, 2003, p. 2-14.

INOUE OKUBO, Yukitaka. Tesis sobre el culto al dios único en la época prehispánica: según dos cronistas indígenas del centro de México. The Journal of Intercultural Studies, n. 27, 2000, p. 209-221.

LARA GARRIDO, José. El motivo de las ruinas en la poesía española de los siglos XVI y XVII. Analecta Malacitana, n. 2, 1983, p. 223-277.

LIENHARD, Martin. La crónica mestiza en México y en Perú hasta 1620: apuntes para su estudio histórico-literario. Revista de Critica Literaria Latinoamericana, n. 17,1983 , p. $105-115$.

LIENHARD, Martin. La voz y su huella: escritura y conflicto étnico-social en América Latina (1492 - 1988). La Habana: Casa de las Américas, 1990.

LIENHARD, Martin. Mesoamérica: la llamada crónica indígena. Literatura Mexicana, n. 1, 1990, p. 9-21.

LOCKHART, James. Los nahuas después de la conquista. Historia social y cultural de los indios del México central, del siglo XVI al XVIII. México: Fondo de Cultura Económica, 2013.

LÓPEZ BUENO, Begoña. Tópica literaria y realización textual: unas notas sobre la poesía española de las ruinas en el Siglo de Oro. Revista de Filología Española, n. LXVI, 1986, p. 59-74.

PASTOR, Beatriz. El jardín y el peregrino. El pensamiento utópico en América Latina (1492-1695). México: Universidad Autónoma de México, 1999. 
POMAR, Juan Bautista. Relación de Tezcoco. In: García Icazbalceta, J. (ed.). Nueva colección de documentos para la historia de México. Tomo III. Pomar, Zurita, Relaciones antiguas (siglo XVI). México: Imprenta de Francisco Díaz de León, 1891, p. 1-69.

ROZAT DUPEYRON, Guy. Indios imaginarios e indios reales en los relatos de la conquista de México. México: Universidad Veracruzana, 2002.

SIMMEL, Georg. "The Ruin”. In: Wolff, K. H. (ed.). Essays on Sociology, Philosophy and Aesthetics. New York: Harper and Row, 1965, p. 259-66.

STAROBINSKI, Jean. "La mélancolie dans les ruines". In: Linvention de la liberté 1700-1789. Genéve: Editions d'Art Albert Skira, 1964, p. 179-187.

VÁZQUEZ CHAMORRO, Germán. "Introducción general". In: Relaciones de la Nueva España. Madrid: Historia 16, 1991, p. 7-15.

María Inés Aldao. Doctora en Letras y Magíster en Literaturas española y latinoamericana por la Universidad de Buenos Aires. Es investigadora del Instituto de Investigaciones en Humanidades y Ciencias Sociales (Facultad de Humanidades y Ciencias de la Educación, UNLP) y del Instituto de Literatura Hispanoamericana (Facultad de Filosofía y Letras, UBA). Es becaria posdoctoral del CONICET. Dicta clases en la carrera de Letras en UBA. Se especializa en el área de literatura colonial. E-mail: mariainesaldao@gmail.com 